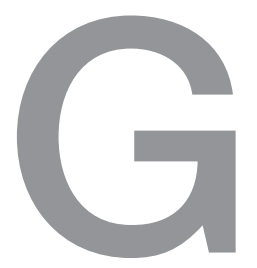

German
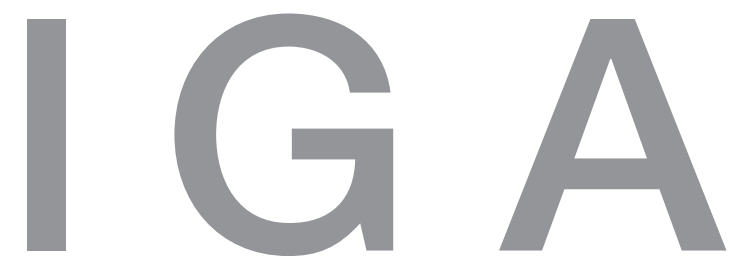

Working Papers

GIGA Research Programme:

Power, Norms and Governance in International Relations

How Signifying Practices Constitute Food (In)security The Case of the Democratic People's Republic of Korea

David Shim

No 122

February 2010 


\section{GIGA Working Papers}

Edited by the

GIGA German Institute of Global and Area Studies

Leibniz-Institut für Globale und Regionale Studien

The GIGA Working Papers series serves to disseminate the research results of work in progress prior to publication in order to encourage the exchange of ideas and academic debate. An objective of the series is to get the findings out quickly, even if the presentations are less than fully polished. Inclusion of a paper in the GIGA Working Papers series does not constitute publication and should not limit publication in any other venue. Copyright remains with the authors. When working papers are eventually accepted by or published in a journal or book, the correct citation reference and, if possible, the corresponding link will then be included on the GIGA Working Papers website at <www.giga-hamburg.de/ workingpapers>.

GIGA research unit responsible for this issue:

Research Programme "Power, Norms and Governance in International Relations"

Editor of the GIGA Working Papers series: Juliane Brach <workingpapers@giga-hamburg.de> Copyright for this issue: (C) David Shim

English copy editor: Melissa Nelson

Editorial assistant and production: Christine Berg

All GIGA Working Papers are available online and free of charge on the website $<$ www. giga-hamburg.de/workingpapers $>$. They can also be ordered in print. A fee of $€ 5$ will be charged for production and postage costs. For orders or any requests please contact:

E-mail: workingpapers@giga-hamburg.de

Phone: ++49 (0)40 - 42825 - 548

The GIGA German Institute of Global and Area Studies cannot be held responsible for errors or any consequences arising from the use of information contained in this Working Paper; the views and opinions expressed are solely those of the author or authors and do not necessarily reflect those of the Institute.

GIGA German Institute of Global and Area Studies

Leibniz-Institut für Globale und Regionale Studien

Neuer Jungfernstieg 21

20354 Hamburg

Germany

E-mail: info@giga-hamburg.de

Website: www.giga-hamburg.de 


\title{
How Signifying Practices Constitute Food (In)security- The Case of the Democratic People's Republic of Korea
}

\begin{abstract}
This paper argues that the question of food (in)security in the Democratic People's Republic of Korea is not necessarily indicative of the country's actual nutritional conditions but is rather constituted through meaning-making behavior-signifying practices-predominantly on the part of humanitarian aid institutions working there. The argument is not intended to gloss over the food and nutritional situation in North Korea or to suggest that famine, starvation, or malnutrition do not exist. The paper nevertheless argues that humanitarian institutions are not external to or separate from the reality they observe, monitor, and measure, but are rather constitutive of the categories which produce that realityin this case food (in)security in North Korea. The undertaking of nutrition surveys, food security assessments, and food-aid monitoring as well as the issuing of consensus statements are examples of aid practices that signify North Korea in terms of vulnerability, emergency, and food insecurity. The paper's central argument is that it is through precisely these observations, assessments, and representations that food (in)security in North Korea comes into being.
\end{abstract}

Keywords: North Korea, food security, discourse, representation, knowledge, humanitarian institutions

\section{David Shim, M.A.}

is a Ph.D. candidate and research assistant at the GIGA Institute of Asian Studies.

Contact: shim@giga-hamburg.de

Website: http://staff.giga-hamburg.de/shim 


\section{Zusammenfassung}

\section{Die Konstitution von Ernährungs(un)sicherheit durch Praktiken der Signifikation am Fallbeispiel der Demokratischen Volksrepublik Korea}

In dem Arbeitspapier wird argumentiert, dass Ernährungs(un)sicherheit in der Demokratischen Volksrepublik Korea nicht unbedingt die realen Ernährungsbedingungen des Landes widergespiegelt, sondern durch Praktiken der Signifikation - überwiegend von humanitären Hilfsorganisationen - konstituiert wird. Diese Argumentation soll jedoch nicht die allgemeine Ernährungssituation in Nordkorea verharmlosen. Es wird auch nicht behauptet, dass Hunger, Unterernährung oder Mangelernährung nicht existieren oder dass Hilfsorganisationen ebenjene Phänomene bewusst erfinden oder herbeiführen. Vielmehr geht es darum aufzuzeigen, dass humanitäre Akteure nicht außerhalb der Realität stehen, die sie beobachten, vermessen und erfahren, sondern konstitutiv sind für jene Kategorien, die diese Realität herstellen - im vorliegenden Fall, die Ernährungs(un)sicherheit in Nordkorea. Humanitäre Hilfe bringt eine Reihe von Bedeutung generierenden Praktiken mit sich (z.B. Untersuchungen der Ernährungssicherheit, Überwachung der Lebensmittelhilfe, Erklärungen über die Ernährungssituation), welche Nordkoreas Ernährungslage dauerhaft als vulnerabel, unzureichend und unsicher darstellen. Das Arbeitspapier veranschaulicht wie Praktiken der humanitären Hilfe eine bestimmte Realität herstellen und konsolidieren, durch welche erst die Ernährungs(un)sicherheit Nordkoreas entsteht. 


\title{
How Signifying Practices Constitute Food (In)security- The Case of the Democratic People's Republic of Korea
}

\author{
David Shim
}

\section{Article Outline}

1 Introduction

2 Constituting Meaning

3 Constituting North Korea's Food (In)Security

4 Excursus: The Practical Difficulties of Assessing the Food Situation in North Korea

5 Conclusion

There are many realities in North Korea $[\ldots]$ there is more than one reality at any given moment in time.

(Noland 2008)

\section{Introduction}

In contemporary international security discourses, the Democratic People's Republic of Korea (DPRK) is often associated with risk and danger, paradoxically emanating from what can be called its "strength" and "weakness": on the one hand, North Korea's military strength, embodied in its missile and nuclear programs and the potential proliferation of related technologies, are considered to be eminent threats to regional and international peace and security; on the other hand, its internal weakness, such as its political, economic, and food crises, are similarly regarded as a menace to peace and stability. 
The mid-1990s appear to have been a defining moment in the problematization of North Korea. Its refusal to admit inspectors from the International Atomic Energy Agency (IAEA) to its nuclear complex at Yongbyon and its threat to withdraw from the Non-Proliferation Treaty (NPT), which almost resulted in a pre-emptive strike by the United States, plus its appeal to the United Nations (UN) for aid assistance to help alleviate the worsening humanitarian situation made the country an issue of international concern.

By focusing on the discourse regarding North Korea's food situation, this paper ${ }^{1}$ argues that the question of its food (in)security ${ }^{2}$ is not necessarily indicative of its actual nutritional conditions but is rather constituted through meaning-making behavior-signifying practicespredominantly on the part of humanitarian aid institutions working in the country. This is not to say that the paper glosses over the food and nutritional situation in North Korea, or that it disregards the work and motives of humanitarian aid workers and their national counterparts. Famine, hunger, starvation and malnutrition are not fantasies, either in North Korea or in global politics.

Due to his work as a food-aid monitor for the United Nations World Food Programme (WFP) in autumn 2008, the author could be expected to view nutritional conditions in North Korea as quite striking, as the many alarming reports, assessments or evaluations of humanitarian institutions would indicate. That is to say, it might be tempting to state, simply because of my personal presence at this humanitarian operation, which is categorized by the WFP as an emergency operation, that the situation or facts spoke for themselves. I went there and witnessed North Korea's reality, so I can thus discern what is "really" going on. However, this assumption, namely, that reality presents itself as it is and can be reflected as though in a mirror, is exactly what this article would like to problematize. For if one is to assume that phenomena "speak for themselves," this would not only denote that meaning lies intrinsically within an object, subject or situation, but would also imply that one and the same meaning can be carved out. This view resembles that of the Italian renaissance sculptor

1 An earlier version of this paper was presented at the $4^{\text {th }}$ International Conference in Interpretive Policy Analysis, 25-27 June 2009, University of Kassel, Germany. The author would like to thank Dirk Nabers and Heike Holbig for helpful comments on earlier versions of the paper. From September to November 2008 the author worked as a food-aid monitor for the United Nations World Food Programme in the Democratic People's Republic of Korea. All information concerning the World Food Programme's operation in North Korea has been derived from publicly available sources.

2 Since the World Food Summit in 1996 food security has commonly been defined as a situation where "all people, at all times, have physical and economic access to sufficient, safe and nutritious food to meet their dietary needs and food preferences for an active and healthy life" (WFS 1996). According to the World Food Programme, food security rests on three pillars: 1) food availability, which "is the amount of food that is physically present in a country or area through all forms of domestic production, commercial imports and food aid"; 2) food access, which "is the households' ability to regularly acquire adequate amounts of food through a combination of their own stock and home production, purchases, barter, gifts, borrowing or food aid"; and 3) food utilization, which "refers to: (a) households' use of the food to which they have access, and (b) individuals' ability to absorb nutrients - the conversion efficiency of food by the body" (WFP 2005: 32). 
Michelangelo, who claimed that his sculpture David was already in the stone and that his only task was to free it.

If such a notion of the possibility of discovering the "real" or "true" meaning of phenomena is accepted, one would agree that it is possible to stand outside the situation in which the phenomenon occurred and observe the unvarnished reality. This notion presumes that someone observing from outside would not be affected by the situation s/he was experiencing. Yet as Foucault (1984: 127) famously noted, "we must not imagine that the world turns towards us a legible face which we would have only to decipher; the world is not the accomplice of our knowledge; there is no prediscursive providence which disposes the world in our favour."

The questions which are of interest here are not whether the supply or distribution of food is "objectively" deficient or whether North Korea is "really" food insecure, as is regularly stated, for instance, by humanitarian agencies. Rather, the question is how North Korea's food (in)security is constituted through the discursive practices of humanitarian institutions. The paper argues that aid institutions are not external to or separate from the reality they observe, monitor or assess, but are rather constitutive of the categories which produce that reality; in this case, food (in)security in North Korea. The discussion demonstrates that the conducting or issuing of food security assessments, consensus statements, food-aid monitoring, or food for community development projects are examples of aid practices which make North Korea recognizable in terms of vulnerability, emergency, and food insecurity. The paper's central argument is that it is precisely these observations, assessments, and representations that produce and maintain a reality through which North Korea's food (in)security comes into being.

The following section presents the theoretical foundations of the paper's argument. Questions of representation, hegemony, and knowledge are central to this part. The discussion here resembles what Nick Vaughan-Williams has called the "problem of history" in the field of international relations (IR), which is the "impossibility of getting historical interpretation one hundred percent right" (Vaughan-Williams 2005: 117). The subsequent section (Section 3) connects the theoretical aspects with the empirical analysis. It demonstrates how knowledge and representational practices (photographs, texts) are interwoven in the constitution of North Korea's food (in)security. Attention is also paid to the methodological difficulties of assessing the food situation in North Korea The final section concludes the discussion and addresses some of the argument's implications. 


\section{Constituting Meaning}

\subsection{Representation}

How is meaning produced? How is meaning "realized," in that it gains what can be called a hegemonic status? How are practices of representation and signification related to this process? The aforementioned example of the author's personal presence in North Korea shall be recalled in order to illustrate the "problem of representation." As the Foucault quote in the introduction suggests, reality does not disclose itself as it is. Or as Edward Said (1978: 21, italics in original) puts it, "there is no such thing as a delivered presence, but a re-presence, or a representation." Both assertions point to epistemological claims according to which meaning does not lie inherently within things, actions, or ideas. The "true" essence or "real" meaning of a phenomenon remains completely unknowable and cannot be transmitted in its full complexity. That is to say that the means of transmission (such as discourse, language, photographs, signs, texts, etc.) are never transparent or complete reflections of an objective truth or material reality, but rather individual meaning-producing practices, which are what constitute truth and reality in the first place. In keeping with Said, only representations of reality can be interpreted in order to make sense of it. It is through these signifying or representational practices that the meanings or identities of things, events or subjects are steadily produced - that is, come into being as such (see also Bleiker 2001; Hall 1997; Shapiro 1988; Doty 1996).

The anti-essentialist assumption does not deny the existence of material facts, events or external reality, but it suggests, in the words of Ernesto Laclau and Chantal Mouffe (2001: 108), "the rather different assertion that they could constitute themselves as objects outside any discursive condition of emergence." For instance, in April 2009 there was an incident in Northeast Asia which involved a rocket being launched into the sky. This was definitely a real event and took place independently of thought. However, this act was in itself meaningless external to the representations, or discourse, with which this rocket was constructed as a North Korean missile. Similarly, the state of North Korea's food (in)security is not constituted as a phenomenon through mere self-reference but is associated with a created discourse resulting from knowledge, practices, theories, and institutions which define the food situation as food secure or insecure (cf. FAO 2006).

Since the congruent transmission of a specific phenomenon-be it reality, truth, or the food situation in North Korea-is not possible, only parts of it can be transferred, something which reveals the structural and inevitable gap in the mediating process (see also Bleiker 2001; Laclau 1993). What follows from this gap is the necessity of filling it through a hegemonic process of representation, in which the void emerges as the very space and condition of all politics (Bleiker 2001: 512). In other words, the meaning of the phenomenon can only come into being if it is represented by something that stands for it. Representation is constitutive of the phenomenon's meaning and is what enables politics to take place at all. How- 
ever, since only extracts or selections of a totality can be transmitted, a representation is also necessarily always a reduction of that phenomenon. So, what is important to note is not only the constitutive or enabling role of representational practices but also their intervening and changing character on how phenomena acquire meaning. New meanings and identities are produced through representation. As Laclau puts it, "no pure relation of representation is obtainable because it is of the essence of the process of representation that the representative has to contribute to the identity of what is represented" (Laclau 1993: 280; 1990: 30). ${ }^{3}$

\subsection{Hegemony}

How is hegemony related to this process of representation? When is a representation hegemonic? For Laclau $(1996 ; 2005)$ one can speak of hegemony, if the structural gap which arises from the impossible representation of a totality is filled with a partial account, which from then on embodies that totality. The achievement of hegemony resembles the rhetorical trope of the synecdoche and entails a standard way of making sense of a specific reality, thereby excluding other, alternative, modes of interpretation and representation. Hegemonic representations can be conveyed visually (see Figure 1) or textually (see the so-called consensus statements of the humanitarian agencies) but always denote the fixation of meaning, that is, what can be seen and said in a meaningful or truthful way. Discursive hegemony is an authoritative interpretative framework in which subjects, objects, and phenomena acquire (new) meanings or, to put it linguistically, in which signifiers are tied to signifieds.

In case of North Korea's food (in)security the standard interpretation construes specific knowledge, elements, or developments as meaningful (aid assistance, UN crop estimations) or meaningless (development assistance, North Korea's crop estimations), something which indicates the political implications of hegemonic discourses. For instance, food shortages and inadequate food self-sufficiency have been a problem on the Korean Peninsula for centuries due to the mountainous area; limited arable land; and a comparatively short growing season, which has resulted in recurrent spring famines (Pinkston/Saunders 2003: 84). However, knowledge concerning the impossibility of attaining food self-sufficiency is rarely incorporated in discourses regarding North Korea's food situation. Another example is the marginalization of North Korean estimates concerning its own food production by humanitarian institutions. This indicates hierarchal knowledge claims within the hegemonic discourse.

3 Laclau problematizes the process of (distorted) representation in terms of democracy theory and populisms and asks for the implications of an accurate representation of a specific will, when the representative not only transforms the identity of the represented but is also constitutive of it (Laclau 1993). Here, however, the process of representation is applied as the condition of reality or truth construction. Nonetheless, as Laclau puts it, this problematic is "inherent in any process of representation" (2005: 158, italics in original). 


\subsection{Knowledge}

When we connect the theoretical framework developed so far with the example of personal presence, it follows that being in North Korea does not necessarily mean that one can provide a "truer" account of what is "really" going on in the country-for instance, with regard to the general food situation. Again, the food situation is not transmitted in its totality to the on-site observer, but is rather made meaningful, that is, comes into being, precisely through the observer's presence and practices. Crucial in this signifying process is the accumulation and representation of knowledge by relief organizations and their aid practices: crop and food security assessments, nutrition surveys, food-aid monitoring, or food-for-communitydevelopment programs. That is to say, the information and knowledge accumulated by aid agencies serve as the foundation for specific representational patterns in which presumptions, facts, conclusions, and claims to exceptional knowledge are inferred. This signifying process illustrates how knowledge is entangled with the constitution of social subjects and meanings. One effect of knowledge that is understood as natural is the exclusion of alternative experiences and knowledge. Furthermore, through the examination, observation, or classification activities of humanitarian missions, specific situations, objects, and social subjects are brought into being, for instance, an "acute food and livelihoods crisis" (RFSA 2008: 1), "WFP food," "beneficiaries," or "flood victims." A prime example of these signifying practices is for instance the Integrated Food Security and Humanitarian Phase Classification of the Food and Agricultural Organization (FAO 2006). ${ }^{4}$ As a result of these designations, subsequent actions or policies such as the regulation of entitled food rations or the inflow of foreign aid workers, administrative staff, and technical and logistic personnel are enabled.

The co-constitution of knowledge and reality refers to what Michel Foucault $(1977 ; 1980)$ called the productive aspect of power and relates to inquiries concerning his engagement with madness, delinquency, and (homo)sexuality. ${ }^{5}$ According to Foucault, the madman, the delinquent, and the homosexual were inventions of emerging modern sciences, such as psychology and criminology, of the eighteenth and nineteenth centuries. These sciences produced the social subjects through knowledge and disciplinary practices (e.g., Foucault 1977; 1984; 1980: Ch. 5, 6). A simple example might clarify the relationship between knowledge and reality. In accordance with the legal principle nulla poena sine lege, one cannot be penal-

4 The FAO differentiates five categories: (1) general food security, 2) chronic food insecurity, 3) acute food and livelihoods crisis, 4) humanitarian emergency and 5) famine/humanitarian catastrophe (FAO 2006). This classification serves also as the basis for WFP assessments.

5 In Discipline and Punish (1977) Foucault gives an account of what is meant by productive power. He refers to the changing penal system in Europe and the United States at the end of the eighteenth century and beginning of the nineteenth. The shift of sovereign power (right to kill) to disciplinary power (imperative to preserve life) led not only to the disappearance of the spectacle of public torture and executions but also to the production of a new kind of subject-the criminal. Individuals become criminals through the introduction of disciplinary practices, such as the surveillance apparatus of Jeremy Bentham's Panopticon, "to carry out experiments, to alter behaviour, to train or correct individuals" (Foucault 1977: 203). 
ized for a deed without the prior existence of a law that prohibits and, in the event of noncompliance, determines a punishment for that deed. That is to say, the "criminal act," and with it the "delinquent," is constituted through a legal discourse which signifies the action and the social subject as criminal. The "delinquent" did not exist extradiscursively or prior to knowledge (law); rather the deed and the subject came into being precisely through the emergence and application of knowledge practices such as laws, theories, and penal institutions.

\section{Constituting North Korea's Food (In)Security}

\subsection{Knowledge and North Korea's Food Situation}

\section{The Accumulation of Knowledge and the Performative Character of Aid Practices}

Before and during humanitarian operations a number of activities are carried out. Some of them are specific aid practices such as on-site food-aid monitoring, crop and food security assessments, nutrition surveys, the definition of target groups, and food-for-communitydevelopment programs. However, these practices do not merely entail the control and appraisal of proper food distribution or food availability at the household or county level. They are intended, according to the UN, "to reflect the national picture" (CFSAM 2008: 31). For instance, during travels to and from monitoring sites, which can last up to half a day, ${ }^{6}$ aid workers collect a range of information intended to expand the knowledge about the (foodsecurity) situation in the country. The information about North Korea-gathered after twenty-five assessment missions conducted by UN agencies between 1995 and 2008 and which also provides the basis for the UN's country database system-includes the following elements:

- Infrastructure (condition of streets, bridges, railways, buildings)

- Economy (activities of street stalls, factories and eventually markets)

- Security (number of security checkpoints and movements at checkpoints)

- Agriculture (type of crops; seeding, harvesting or lean season; use of irrigation and fertilizers)

- People and their livelihoods as well as health and nutrition issues (collection of and bartering for food; rehabilitation work in the streets, villages or cities; observations regarding diet, income, occupation, poverty, begging, neglected children)

The widely accepted and applied aid practices of humanitarian relief work can be considered to be knowledge-producing practices, which in turn create a social subject-the beneficiary.

6 The institutions to be monitored-kindergartens, nurseries, hospitals, local food production facilities, and public distribution centers-are dispersed throughout the counties, meaning that hours of travel are sometimes required. 
As previously noted, Foucault pointed to knowledge systems such as criminology or psychology that constitute the process through which subjects ("delinquent," "madman"), objects ("prisons," "mental institutions"), or situations ("felony," "madness") appear (e.g., Foucault 1977; 1988). These subject or objects were not pre-given, in the sense that they only had to be discovered; but came into being through knowledge-producing practices.

In this sense, the aid practices of humanitarian agencies determine the identity and meaning of social subjects and food (in)security in the first place. Accordingly, beneficiaries, target groups, and vulnerable populations were not already "there" - that is, prior to the relief engagement of the humanitarian organizations. They became these subjects at the very moment when aid practices such as food security, crop and flood assessments began to proliferate. For instance, the WFP's practice of defining so-called "target groups" is a performative act which signifies people or groups of people as "flood victims" or "food-for-communitydevelopment" participants. A prime example of how food-aid practices produce social subjects is the identification of so-called "other vulnerable groups" (OVG) as part of the WFP's 2008/09 emergency operation (EMOP 2008: paragraph 27). As the organization's emergency assessment report notes,

WFP will introduce a new beneficiary group [...] which is intended to cover adolescents, the handicapped and workers in low-productivity factories, amongst others. The same food can also be used to address deepening vulnerability among existing beneficiary categories. In the event that staff of beneficiary institutions are found to be food insecure, they would be eligible for inclusion under this category (OVG) [...] if WFP field monitoring visits reveal the emergence of new vulnerable groups or patterns of deepening vulnerability, each sub-office in consultation with provincial and county officials will have food stocks to immediately respond to the problem.

(EMOP 2008: paragraph 27, 39)

This excerpt points not only to the dependence of beneficiaries on aid workers' assessments and monitoring in order to receive food, but also to the signification of subjects as beneficiaries ("adolescents," "workers") through the practices of food aid and the presence of food-aid monitors. To put it simply, the allotted food is what constitutes the beneficiaries in the first place. It is in this respect that these practices contribute to the constitution of a specific reality rather than simply reflecting it. What can be inferred from the paragraphs above are the productive and transformative effects that humanitarian practices have on the formation of North Korea's (food) reality. ${ }^{7}$

\footnotetext{
Aware of these transformative effects, the North Korean government has imposed strict regulations concerning the terms of operation and the movement of humanitarian workers. For instance, since the initiation of humanitarian operations in North Korea in the mid-1990s, interaction between foreign aid workers and the North Korean people has been restricted. This points to North Korea's politicization of the presence of foreign aid workers and international humanitarian institutions. Another important aspect is the politicization of
} 


\section{The Void of Knowledge}

It is often claimed that little is known about the DPRK. The country seems to be the veritable antithesis of capitalist globalization. Its ideology, society, and economy are deemed to be outdated, and the collapse of its system is seen as being only a matter of time. North Korea is said to be the most isolated country in the world ${ }^{8}$ and therefore a timeless "mystery" (Scalapino 1997), "enigma" (Halliday 1981), or "terra incognita" (Schwekendiek 2009). While this supposed absence of data does not prevent scholars from compiling, dispersing, and depending on information concerning North Korea, it does denote the presupposition of a genuine void of knowledge.

Many scholars argue that humanitarian organizations played a central role in "opening up" (Smith 1999) North Korea to the outside world after Pyongyang appealed for assistance in the mid-1990s (e.g., Feffer 2006; Flake 2003; Lee 2003; Reed 2008, 2005; Smith 2000, 2005, 2007; Schloms 2003; Snyder 2003a/b). Humanitarian workers and institutions are said to be "agents of change" (Feffer 2006: 20) who function as informants about what is going on in the DPRK. Or as Snyder (2003a: 12) puts it, aid institutions "provide the world with a window on the real North Korea." Regardless of whether relief organizations in North Korea "spread new ways of thinking about the outside world" (Reed 2008: 187) or whether "aid workers contribute to changing the very environment in which they work" (Feffer 2006: 20), almost all accounts stress the role of humanitarian organizations in closing a presumed gap regarding knowledge about North Korea. An excerpt from Snyder (2003a: 2, 12) demonstrates the extent to which humanitarian agencies are credited with the generation of knowledge about it:

The voluntary admission of international humanitarian aid workers [...] marked the beginning of the end of North Korea's hermetic isolation [...] The international humanitarian response in North Korea [since the mid-1990s] was the first practical vehicle through which it has become possible to work inside North Korea and therefore provides an opportunity to learn more about the needs of the country and to gauge firsthand its capacity and willingness to move forward with the system changes that are necessary for rehabilitations. The experience and influence of the humanitarian aid community have extended to policy formation in the form of an increasingly expanded database for understanding North Korea's internal structure, organization, and intentions.

Snyder and others (especially Smith 1999, 2005) suggest that humanitarian institutions contributed to increased knowledge about North Korea by accumulating and systematically dis-

space in aid operations in North Korea on the part of Pyongyang, through its partial refusal of (random) access to monitoring sites, and on the part of the WFP, through its 'no-access-no-food' policy.

8 Such statements refer mostly on the country's assumed lack of participation in regional or global politics. However, if measured for instance in terms of official diplomatic relations, North Korea is not even remotely as isolated as Taiwan 
seminating information, data, and statistics about the country's economic, social, cultural, and political organization. ${ }^{9}$ It is important to highlight the connection between the humanitarian agencies' generation of knowledge and the constitution of North Korea's (food) reality. What the above-cited passage describes is the emergence of international aid institutions as the premier sources of information and their subsequent role in the representation and constitution of North Korean reality. It further points to the supposed existence of a veritable void of knowledge before aid institutions came in to fill it. However, it is crucial to stress that the knowledge (for example, nutrition surveys, crop and food security assessments) accumulated by international aid institutions is not neutral information per se; it is itself already an interpretation. In other words, humanitarian institutions do not "provide the world with a window on the real North Korea" (see quote from Snyder above) but are rather constitutive of the "real North Korea" precisely through their knowledge-generating practices (see also Doty 1996).

The quantitative and qualitative increase in knowledge about the DPRK due to the practices of humanitarian organizations is not necessarily challenged here, although specific questions regarding the (un)availability of information and knowledge will be raised below (see page 26). However, the assumption of North Korean observers such as scholars, journalists and aid agencies that little is known about the country, which is often combined with the depiction of North Korean society's supposedly closed "nature," sidelines the country's experience and encounters with actors others than the West before the presumed "opening" of the mid1990s. It neglects, for instance, North Korea's engagement with predominantly developing countries in the 1970s, which sheds light on the country's political, economic, diplomatic, and cultural relations with former Eastern bloc states and (members of) international institutions such as the Non-aligned Movement (NAM), and the Group of 77 (G-77). As Krishnan (1981: 313) concludes with respect to North Korea's role in the NAM, "the DPRK's membership of the non-aligned movement has provided it with a tremendous scope and opportunity to interact more effectively with other developing countries in promoting further its trade, economic, scientific, technical, and cultural relations." ${ }^{10}$ One question which could arise, then,

9 The accumulated knowledge about the country also served to inform governments. As the former US defense secretary William Perry stated, "the best source of information that I got was from relief agencies who were over there, not just in Pyongyang, but in the villages all over North Korea" (cited in Snyder 2003a: 12).

10 Especially in the 1970s, when North Korea was admitted to various international organizations and UN institutions such as UNESCO, NAM, IAEA or WHO, Pyongyang proved its capacity to play an active and effective role in international diplomacy. In this period, the diplomatic activities of North (and also South) Korea focused mainly on its exclusive claim to the authority to represent the Korean peninsula at the international level. For instance, the decision of the Foreign Ministers' Conference of the NAM in 1975 to accept North Korea's membership application and reject South Korea's at the same time indicated Pyongyang's diplomatic savvy (Kim 1997: 83). Another example is the long-standing demand for the withdrawal of all foreign-de facto US - troops on the Korean Peninsula on the part of the North Korean leadership. This demand was supported at the 1970 and 1972 conferences of the heads of states and foreign ministers of the NAM, who stated 
regards the extent of knowledge and experience gained by North Korea through contacts and exchange with other countries before the mid-1990s.

The reading of a supposed knowledge gap regarding North Korea on the part of its observers suggests the understanding of a specific historicity, according to which North Korea is represented as a blank space waiting to be filled in by them. It gives rise to the narrative that North Korea was "opened up" (Smith 1999) by aid agencies. That is to say, the food (in)security discourse can be said to function as a means by which North Korea's historicity emerges as a result of the humanitarian agencies' ways of knowing.

\section{Exceptional Knowledge}

Another effect of the aid agencies' generation of knowledge regarding North Korea is the restriction of who is entitled to speak and act with regard to its food situation. For instance, in 2005 North Korea asked the UN to shift its assistance from aid to development projects, citing, among other things, good crop yields. While humanitarian aid comprises primarily lifesaving or life-sustaining measures such as the supply of food, water and medicine, development assistance attempts to build or sustain capacities for self-reliant development. ${ }^{11}$ The demand of the North Korean government could be seen as an attempt to reduce its reliance on food shipments after ten years of foreign aid assistance. To the UN (and others) this demand did not make sense; responding to the proposed transition from aid to development projects, then undersecretary-general for humanitarian affairs Jan Egeland determined what should be regarded as appropriate action by stating, "In our view, the humanitarian crisis is continuing. There's still a great shortage of food [...] and therefore the humanitarian agencies are doing a very important and necessary job."12 A consequence of this dismissal of North Korea's proposal was the negation of its effective agency by another WFP spokesman. Referring to North Korea's inability to cope with the current situation alone, which would thus necessitate the presence of humanitarian relief organizations, the official claimed: "Our view is that, yes, the humanitarian situation in the North has improved, but not to the extent to which the country can do without humanitarian aid."13

The marginalization of North Korean statements by UN agencies can be still observed today. In autumn 2008 the North Korean agricultural ministry reported an expected increase in crop

that the presence of foreign forces was a threat to international peace and security and demanded the pullout of all foreign troops (Krishnan 1981: 310).

11 As Christine Ahn (2005) puts it, "the difference between sending food aid versus development assistance is the difference between sending one kilogram of corn versus one kilogram of maize seeds that can yield 180 kilograms of corn.". The question whether to provide aid or development assistance is important because the latter "brings into play a completely different set of organizations and approaches" (Edkins 2000: 73).

12 “N. Korea asks UN agency to halt ops," The Straits Times Interactive, 18.03.05.

13 “N. Korea seeks shift in food aid," International Herald Tribune, 09.09.05. 
yields for the same year. These assessments were immediately challenged by the UNICEF representative in Pyongyang: "We [UN agencies] think the North's estimation was wrong". ${ }^{14}$ The UN's certainty regarding the necessity of continuing aid operations (instead of initiating development projects) points to a mode of knowledge which can be described as exceptional knowledge (Inayatullah 2009). By stating what is (in)appropriate, the UN reveals its claim that it possesses exclusive knowledge: North Korean estimations are "wrong", while UN projections are "intended to reflect the national picture" (CSFAM 2008: 31); the UN knows what is right for the aid recipient North Korea and sidelines its knowledge by pointing to the (assumed) inability of Pyongyang to manage and assess its own situation. The consequences are foreseeable and often results in the mantra-like assurance of the North Korean government to defend its independence, sovereignty and integrity. As Inayatullah (2009: 346, italics in original) aptly states, "the more genuinely I believe that I am providing you with a necessary good, the less I am likely to worry about how I provide that good and whether you experience it as an imposition." Exceptional knowledge connotes an unequal relationship in which the hierarchical subject positions of "donor" and "receiver" are cemented and the effective agency of the receiver is denied (as indicated above by Jan Egeland's quote). Furthermore, the marginalization of North Korean knowledge results in what can be described as "subjugated knowledges", meaning "a whole set of knowledges that have been disqualified as inadequate to their task or insufficiently elaborated" (Foucault 1980: 81).

\subsection{Representation and North Korea's Food Situation}

\section{Imaging North Korea's Food Reality}

Visual representations are crucial for international politics because they are among "the principal ways in which news from distant places is brought home" (Campbell 2007: 220). They entail political consequences because of their role in shaping private and public ways of seeing (Bleiker/Kay 2007). They can have powerful effects, since governments, international organizations, and the public are almost always pressed to take action when confronted with images of humanitarian emergencies. Humanitarian disasters are usually conveyed through media representations (Lisle 2009; Campbell 2007: 220-225; Moeller 1998; Benthall 1993; Postman 1987; Campbell 2003). As Debbie Lisle (2009: 148) puts it, "we see that the objects, issues and events we usually study (for example, wars, revolutions, invasions, treaties) do not even exist without the media [...] to express them" (Lisle 2009: 148). Media representations are also crucial in producing humanitarian situations as events through the generation of public awareness and the mobilization of remedial actions. Despite the obvious importance of visual representations in global politics, little attention is paid to analyzing them in the field of IR. However, some scholars, such as Bleiker (2001; 2006) Bleiker/Kay (2007),

14 “UN says N. Korea may face $4^{\text {th }}$ consecutive year of food shortage," Yonhap News Agency, 23.10.08. 
Campbell (2007), and Pusca (2009), argue that aesthetic insights should be included in IR inquiries in order to enhance the understanding of the "phenomena of world politics and to address the dilemmas that emanate from them" (Bleiker 2001: 519).

A (color) photograph suggests the ability to witness reality as it is. As one among several modes of representation, photography has a unique quality since, as Michael Shapiro (1988: $124)$ asserts, "it is the one most easily assimilated into the discourses of knowledge and truth, for it is thought to be an unmediated simulacrum, a copy of what we consider the 'real'" (see also Barthes (1977). The photograph possesses a quality of representation which scholars term mimetic (Bleiker 2001), reflective, (Hall 1997) or documentary (Hamilton 1997) and which implies the possibility that the viewer can see the unvarnished truth with his/her own eyes. However, as Campbell (2007: 221) argues, photographs "are necessarily constructions in which the location of the photographer, the choice of the subject, the framing of the content, the exclusion of context, and limitations on publication and circulation unavoidably create a particular sense of place populated by a particular kind of people." A photograph is neither objective nor neutral, since it is already an interpretation (Butler 2009: 71). That is to say, photographs produce meaning because they determine what kinds of objects and subjects can be seen and how they are made visible. Photographs are by definition reductions of a given complexity since only parts of it can be pictured. Therefore, they can not only be characterized as visual synecdoches but they also serve, in Laclauian terms, as visual figures of hegemony, since the photographic parts visually embody the whole (cf. Laclau 2000; 2005 Ch. 4).

As mentioned above, a reduced representation also translates into the modification of what is represented. In other words, photography is inevitably transformative of meaning because of its selections and reductions, which create a different, and thus new, meaning of what is pictured. Although the photographs and video coverage of humanitarian operations in North Korea are not as widespread as, for instance, imagery of humanitarian missions in some African countries, pictures and videos have nevertheless been circulated through the media. ${ }^{15}$

15 The relative lack of visual images of North Korean miseries could be explained by the heavily restricted access of foreign press and media. During the late-1990s, in an attempt to raise publicity and increase the food-aid commitments of donors, the World Food Programme (WFP) sent photojournalist Hilary Mackenzie to North Korea to document what was widely believed to be a famine. The publication of Mackenzie's famine pictures resulted in her expulsion and the near expulsion of the WFP (Natsios 2001: 190). 
Figure 1: $\quad$ A Nation's Hunger in a Child's Face

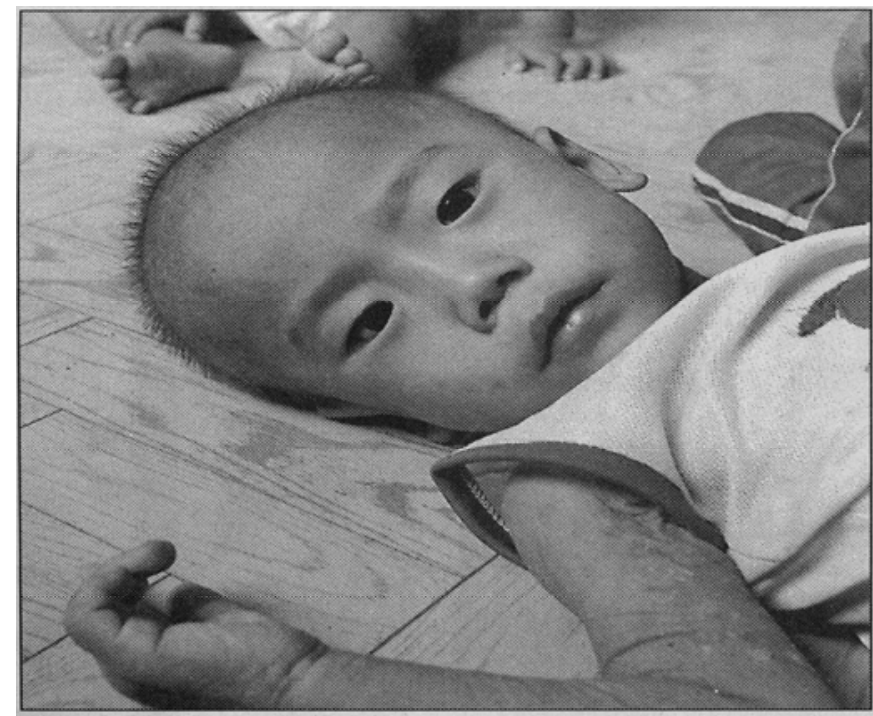

\section{A nation's hunger in a child's face}

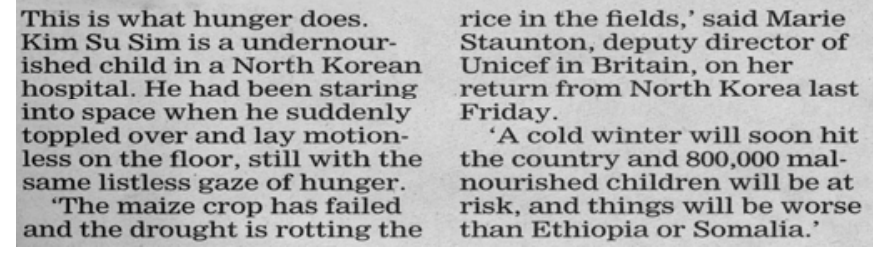

Source: www.imaging-famine.org (accessed 17.01.09).

One picture (see Figure 1), printed in the Guardian on August 18, 1997, shows a child lying on a floor in a North Korean hospital with the heading "A nation's hunger in a child's face." The caption suggests to the reader "what hunger does," describing how the boy, due to hungerinduced fatigue, "suddenly toppled over and lay motionless on the floor." The angle from which the photo is taken as well as its comments ("lay motionless on the floor") allots the subject (and also the viewer) of the picture a specific position. It conveys a passiveness and a sense of being exposed on the part of the subject (which also suggests a certain degree of inferiority for the subject relative to the viewer). The monochrome composition of the image exemplifies the reduction of North Korea's reality to shades of grey (see also Hamilton 1997). ${ }^{16}$

This picture epitomizes a hegemonic representation, with the "motionless" and "listless" child embodying the "nation's hunger," - that is, the suffering and plight of the people of the DPRK. It provides the reader with an interpretative frame of reference, which allows the reading of the image only in specific ways and also regulates the (in)visibility of objects, sub-

16 Colors can (de)emphasize certain elements or sections of an image, drawing the attention of the viewer to particular elements (Rose 2001). 
jects, and circumstances (Butler 2009). ${ }^{17}$ Like the synecdoche, the partial content (boy) assumes the role of a legitimate representation of the whole (nation), thereby revealing the hegemonic character of this depiction. The picture-together with its captions-purports to offer a snapshot of the nutritional conditions in the country, indicating that North Korea's reality is proceeding in the same way as the boy's. The part (boy) becomes constitutive of the being's whole (nation's reality) (Chandler 2007: 133). Synecdochical representations can be crucial in mobilizing and facilitating action, since they suggest a causal connection between the well-being of a child and the well-being of an entire country. By reducing complexity, they increase the incentive to act, "to do something," and imply that actions will be effective. It is important to note the link between the enabling of effective actions and synecdochical representations. As Charlotte Epstein (2008: 112) notes, "'synechdochism' in ethnology constitutes a set of beliefs or practice in which a part of an object or person is taken as equivalent to the whole, so that anything done to the part is held to impact the whole."

\section{Writing North Korea's Food Reality}

In 1995 North Korea appealed to the UN to help alleviate the worsening humanitarian situation. Not only the appeal for humanitarian assistance but also the subsequent arrival of numerous foreign aid workers and international humanitarian institutions were unprecedented. It is widely accepted and acknowledged by humanitarian agencies that the event that triggered the appeal was a famine that killed up to three million people. ${ }^{18}$ Again, this paper does not question the occurrence of the event. However, the various, quite contradictory reactions among humanitarian institutions show that multiple interpretations of North Korea's food situation are always possible. That is to say, even in putatively "clear" cases such as that of North Korea in the mid-1990s (but also with regard to the assessment of its general food and nutritional situation) interpretive struggles take place, with various interpretations competing with each other for the prerogative to make sense of the situation. The so-called Consensus Statement, issued by the aid organizations between 1998 and 2000, can be regarded as having established a standard interpretation of what was going on at the end1990s (UN 1999, 2000, 2001).

The accounts of Andrew Natsios (2001: 168-177; see also Smith 1999; Morton 2007; RRN 1997), then vice president of World Vision, suggest that it was not clear from the beginning that the situation constituted a famine. Among humanitarian organizations there was dissent as to whether the situation should be categorized as a famine, a food crisis, or a chronic food shortage, each of which would enable a different set of actions. While the situation was

17 For instance, smiling North Koreans are rarely pictured and, consequently, invisible. A good example of this hegemonic visuality is Tomas van Houtryve's (2009) recently published photo essay in Foreign Policy titled "The Land of No Smiles."

18 The number of casualties is highly contested and varies extremely from 200,000 to 3.5 million (Schloms 2004: 115-120). 
viewed as a massive famine by the US NGOs, the European Union and European NGOs were more cautious and were skeptical of these alarming claims. For Natsios (2001: 172) these divergent representations reflected "some of the profound interpretive disputes argued within the humanitarian and diplomatic communities" regarding North Korea's food (in)security status. ${ }^{19}$ Interestingly, what ultimately happened was what he (ibid. 169) describes as "when aid agency assessments fail": the meaning of the event was debated and defined, thereby revealing the impossibility of the self-signification of the phenomenon and necessitating hegemonic articulations, which read the situation as a "famine in slow motion" (Smith 1999: 471). ${ }^{20}$

In 1996 Sue Lautze of the US Agency for International Development (USAID) and Lola Nathanail of Save the Children UK conducted assessments regarding the needs and requirements for food assistance to North Korea. The findings from both missions proved to be contradictory and sparked an intense controversy about the country's food situation. As Natsios (2001: 172) notes, the "observations and conclusions of the two authors, both technical experts in their disciplines, visiting the same country at the same time, stand in remarkable contrast to one another." While the Lautze report, for instance, observed that in farming households in flood-affected rural areas families were weakened due to the shortage of food and that "other household members [were] fully occupied with foraging for survival" (Lautze 1996), Nathanail, in contrast, identified some food stress but no acute undernourishment or need for additional feeding (cf. Natsios 2000: 172; Smith 1999: 458). Haggard and Noland (2007: 89) report on other assessments which found no indication of widespread malnutrition or hunger. Hazel Smith (1999: 458-462), in her summary of UN and NGO reports, supports the ambiguity of the country's food situation. As she notes, cases of widespread malnutrition were observed but there was "no corroboration of the various scare stories emanating from outside the country as to widespread famine in terms of 'millions' of deaths or of cannibalism" (ibid. 461-462). Referring to the situation in the late 1990s, then UN humanitarian coordinator in North Korea David Morton states, "there was no agreement amongst the remaining agencies and NGOs about the overall humanitarian situation in the country" (Morton 2007: 212).

This interpretational impasse continued until the end of the 1990s and led to the issuance of the so-called Consensus Statement, which were announced by the aid agencies working in the country in 1998 and renewed in subsequent years (UN 1999, 2000, 2001). The consensus

19 Natsios (2000: 173, 174) thinks Lautze's report is more accurate but criticizes her conclusion since it "contradicts both the tone and substance of much of the rest of the report." Natsios also reports on an on-site consortium of Christian NGOs and churches from Canada, which supports Nathanail in some aspects (ibid. 174; see also Smith 2005: 127).

20 Likewise, Hazel Smith (2009: 253) points to a debate around the question of whether the situation should be regarded as a failure of food availability, which denotes the lack of food, or accessibility, which refers to the lack of access to available food. 
statements not only referred to the operating conditions (adequate access, assessment, monitoring) and the effects of the relief activities of the humanitarian institutions ${ }^{21}$ but also framed the food (in)security situation in the DPRK. Developed in an attempt to end the interpretational stalemate, the statements provided a focused snapshot which became the valid representation of the overall food situation in North Korea. In other words, they were hegemonic interventions which established a dominant interpretative framework for making sense of the event in a credible and enduring way; they determined what was going on ("humanitarian crisis in the DPRK is still ongoing," UN 2000), what was necessary ("humanitarian assistance is still required," UN 1999), and who the legitimate agents of knowledge were ("all UN agencies, NGOs and donor agencies operating in the DPRK," UN 2000, see also UN 1999).

The endorsement of the consensus statements by "all UN agencies, NGOs and donor agencies operating in the DPRK" as well as the "unanimous agreement" (UN 2000) on the meaning of the situation in North Korea ("ongoing humanitarian crisis," UN 2000) demonstrates that previously contested and divergent interpretations no longer existed as a result of the statements; additionally, the unity of the humanitarian agencies demonstrated through the statement indicates the emergence of particular claims to knowledge and authority. The statements not only determined the standard reading of the mid-1990s food situation but also served as an interpretive pattern for today's representations of North Korea's nutritional status-as direct comparisons or the references of many recent reports reveal. Newspaper headings (for example, "UN says North Korea facing worst food crisis since 1990s," International Herald Tribune, 30 July 2008; "The Next Great North Korean Famine," Time Magazine, 6 May 2008), academic publications (e.g., Haggard/Noland/Weeks 2008a/b; Haggard/Noland 2009; Lankov 2008), UN assessments (RFSA 2008; CFSAM 2008), and the implementation of the latest humanitarian operation in North Korea indicate the prevailing interpretive frame for making sense of the country's food reality,

In September 2008 the WFP began its latest humanitarian operation in the DPRK. ${ }^{22}$ According to the UN's Rapid Food Security Assessment, jointly conducted by the WFP and the Food and Agriculture Organization (FAO) in June of the same year, some provinces would face an "Acute Food and Livelihoods Crisis," which could become a "Humanitarian Emergency" unless food assistance was provided promptly (RFSA 2008: 3). On the basis of a more comprehensive UN study published in December 2008, it was expected the country would face cereal deficits due to low yields, which would mean that food assistance to meet the basic

21 To address the concerns of humanitarian organizations regarding appropriate operating conditions, a set of "humanitarian principles" were worked out between 1998 and 2001. However, four NGOs left North Korea between 1998 and 2000 citing restrictions on operating conditions (Smith 2002: 7; 2005: 127).

22 Initially the mission was intended to last until November 2009. However, in March 2009, the North Korean government decided not to further accept US food aid. This led to the ending of the US NGOs' operations and downscaling of the WFP's activities. 
needs of 8.7 million people would be required (CFSAM 2008). The WFP's country director for North Korea feared that "millions of vulnerable North Koreans [were] at risk of slipping toward [a] precarious hunger level." ${ }^{23}$ The UN special rapporteur for human rights in North Korea also stated that millions were facing "severe deprivation" not seen in a decade. ${ }^{24}$ These opinions were shared by some of the well-known scholars studying the DPRK. Although Stephen Haggard and Marcus Noland explicitly criticized UN data and figures, they concluded that "North Korea [was] once again poised on the brink of famine" (Haggard/Noland 2008: 1; see also Haggard/Noland 2009; Haggard/Noland/Weeks 2008a/b). Andrew Lankov (2008) also asserted that the country would face an "unprecedented food crisis since the 1990s."

In contrast to the above views were the alternative representations provided by some South Korean humanitarian organizations, South Korean government authorities, and European aid workers. These groups depicted the conditions as being less dire or alarming than the UN and the scholars cited above claimed them to be. For instance, Daily NK, a South Korean organization working for democracy and human rights in North Korea, reported that North Korean wholesalers and market traders expected an exceptionally large increase in the 2008 harvest due to favorable weather conditions. The group's report went on to say that the significantly larger grain harvest would lead to lower prices for rice and maize, thereby considerably easing the country's food shortage (IFES 2008). ${ }^{25}$ The South Korean National Intelligence Service stated in a briefing to parliament in May 2008 that the "food situation in North Korea [was] not as bad as it was in the mid-1990s when more than two hundred thousand people died of starvation" (Choi CH 2008). South Korea's Unification Ministry buttressed this evaluation, noting, "there were no major floods in North Korea this year. The weather condition this year [2008] has been very favourable. It's our assessment that the current condition does not represent a serious crisis situation." ${ }^{26}$ Similarly, field visits by European aid consultants, who went to the DPRK between March and April 2008 on behalf of the European Commission's Directorate General for Humanitarian Aid (ECHO), found "no conclusive signs of large humanitarian emergency needs in DPRK" and concluded - in contrast to UN warnings of a humanitarian crisis - that the "remaining problems and their solutions are firmly within the realm of development" (ECHO 2008: paragraph lx). ${ }^{27}$

23 “UN says North Korea facing worst food crisis since 1990s," International Herald Tribune, 30.07.08.

24 "North Korean food crisis worsens," International Herald Tribune, 24.10.08.

25 In addition, in December 2008 North Korea reported that it expected a significant increase in its potato harvest ("N. Korea expected to harvest 3 million tons of potatoes: official," Yonhap News Agency, 21.12.08).

26 “UN Officials Seek More Aid for North Korea," The Korea Times, 24.10.08.

27 In their report the consultants acknowledged that the food situation (first half of 2008) was "subject to widely diverging estimates, ranging from a worrying food gap (FAO, WFP) to a much less critical deficit (EC)" (ECHO 2008: paragraph xxii). The report went on to cite a food security specialist of the European Commission's Directorate General for External Relations who stated that the analysis of the FAO and WFP-and hence their decision to issue a pre-alert signal-was exaggerated (ECHO 2008: paragraph 208). 
Regardless of which of the recent accounts is the most accurate, they collectively demonstrate "that within each realm of policy discourse it is possible to construct, in its own terms, a competing narrative that denaturalizes and unsettles the dominant ways of constructing the world" (Campbell 1998: 172). The alternative framing of North Korea's food situation by South Korean and European agencies renders ambiguous the predominant tenet, which warns of a humanitarian emergency, and reveals the material consequences and political character of making sense of reality. ${ }^{28}$ However, the emergency operation by the UN in 2008, the responses and appeals from governments and NGOs warning of a severe humanitarian crisis, and the alarming reports from newspapers and academic studies point to a discursive framework which has increasingly equated North Korea's food situation with insufficiency, vulnerability, and calamity.

\section{The UN's Role}

A special role in framing North Korea's food (in)security can be attributed to UN agencies since other actors such as the press, scientists, policymakers and other humanitarian organizations view the UN as credible and, therefore, refer to or disseminate UN data. UN agencies have been in a comparatively favorable position relative to other international relief organizations with regard to establishing contacts with the DPRK government as they were the first to enter the country in the 1980s. ${ }^{29}$ Because of their established relationship with the government, UN agencies (along with two NGOs) were also the first to respond to North Korean appeals for humanitarian assistance in the mid-1990s (Smith 2005: 113). Through the WFP's early and constant humanitarian engagement as well as its comprehensive logistics capabilities, the organization gained an exceptional operating position in the DPRK, which, according to its own statements, allows it to "scale-up any necessary surge in operations" (CFSAM 2008: 33). The intention here is not to deny the WFP's humanitarian contributions, but rather to stress its importance in North Korean humanitarian politics; the UN agency "has now become an essential crutch upon which North Korea depends for its survival" (Snyder 2003a: 8). The WFP has been not only the main provider and distributor of humanitarian aid but also the chief negotiator in discussions with the North Korean government on behalf of the humanitarian agencies operating in the country (Smith 2005: 101). The WFP is also the key actor in terms of manpower and financial resources.

The post of the UN Humanitarian Coordinator, which is located within the WFP, is one expression of the UN agencies' exceptional position. It not only enables the appointee to spur and facilitate consensus building among the humanitarian institutions but also grants

28 That is to say that while the UN were to start one of the largest humanitarian operations in its history, the South Korean government for the first time denied humanitarian assistance to North Korea.

29 The United Nations Development Programme (UNDP) established an office in Pyongyang in 1980. The United Nations Children's Fund began its work in North Korea in 1985. The FAO and the WFP reached a "Basic Agreement" with the government in 1986 (Smith 2005: 108; 113). 
him/her privileged access to government officials. Morton (2007: 212), the UN humanitarian coordinator from 1998 to 2002,30 refers to this institutionalized capacity as follows:

a weekly inter-agency meeting was chaired by the Humanitarian Coordinator and attended by all UN agencies, NGOs, the European Commission and donor representatives, and served as the main forum for coordination and discussion of all humanitarian issues [...] the Humanitarian Coordinator was asked on behalf of the inter-agency group to take up issues with the government and, in general, the government accepted the Humanitarian Coordinator as spokesperson for the community. ${ }^{31}$

In addition, as of 1998 the UN coordinated the annual humanitarian appeal mechanism of all relief institutions operating in North Korea, thereby increasing its weight in the country's humanitarian politics. The so-called Consolidated Inter-Agency Appeal was an integrated approach which functioned as a worldwide instrument to synchronize responses to humanitarian crises. It provided a more integrated channel to raise awareness of the food situation in the DPRK and communicate this to the outside world than the fragmented responses and appeals that had previously been made by the individual humanitarian institutions (Smith 2005: 102-114).

\section{Excursus: The Practical Difficulties of Assessing the Food Situation in North Korea}

The assessment, evaluation and monitoring of situations bring with them several difficulties, including questions regarding the reliability, coherence and methodology of these practices. A UN report from 2008 summarizing North Korea's crop and food security provides insights into the "key limitations," of such assessments (CFSAM 2008: 23). These were noted as follows:

firstly, the length of fieldwork was short and therefore time spent in each province was limited and resulted in only 3-5 household interviews. Secondly the households interviewed were selected by government authorities and were not randomly picked. Thirdly, there was a sense that interpretation of questions and responses may have been misunderstood or incomplete reflecting cultural sensitivities. ${ }^{32}$

With reference to the translation and language barriers that might arise during assessment or monitoring missions, Edkins (2000: 96) observes that "the potential for misunderstandings

30 Morton was also WFP representative, UNDP country director, and UN resident representative.

31 The above-mentioned consensus statements were issued under the chairmanship of the Humanitarian Coordinator.

32 CFSAM 2008: 23. A team of the US NGO's conducting a food-security analysis also faced "significant constrains $[\ldots]$ which [...] likely affected the results of the assessment" and were related to the selection of institutions and households, the collection of data, and the reliability of the information provided (US NGO RFSA 2008: 6). 
[during monitoring visits] is high given the language difficulties, the stressful nature of the visits, and the speed with which the interviews take place." The issue of language barriers might raise questions such as how it can be ensured that aid workers receive the proper translation or whether they are being shown the institutions, sites, or beneficiaries they have asked to see. It follows that international aid workers are necessarily dependent on the cooperation of their national counterparts in fulfilling their assessment missions.

A further issue is the availability of information, and statistics on North Korea. This is not to say that this paper aims to question the reliability of the available data or to provide the reader with newly investigated "hard facts." Rather, it aims to direct attention to an ambivalent situation in which many scholars (and also journalist, policymakers, and international institutions) claim to have only unreliable or scarce information about North Korea, something which would make the research situation unique or difficult. However, this "lack" of information does not appear to keep them from publishing data, drawing conclusions, and recommending actions as many reports, statements, and figures are constantly being released.

A good example of this ambivalence is provided by Kim et al., who published an assessment of the food situation in the DPRK at the end of the 1990s (1998; but see also Chae/Zang 2002; Eberstadt 2007, 1999; Kwon 2009; Noland 1997; Scalapino 1997; Schloms 2003; Schwekendiek 2008). Although the authors claim that "little is known about North Korea's food production and consumption," they nonetheless "assess North Korea's grain consumption and production" by using "indirect indicators, circumstantial evidence, and inferences" (Kim et al. 1998: 520). A more recent example is provided by Kwon (2009). As he admits, "it is very hard for outsiders [...] to evaluate the food situation facing North Korea correctly." However, this does not prevent him from "review[ing] the food situation facing North Korea"; he even takes a step forward and explores "prospects for developments on this matter in years to come" (Kwon 2009: 47). It can be concluded that the (supposed) unavailability of information concerning North Korea is no obstacle to producing research and analysis since information and knowledge are, as Walter C. Clemens Jr. (2008) demonstrates, nevertheless accumulated, disseminated and relied upon. According to Clemens' bibliographical study, almost 240 English-language titles were published on the DPRK between 1997 and 2007.33

In addition to the issue of information (un)availability, there is an academic debate surrounding the reliability of published material. Data and figures published on the DPRK are primarily provided by UN agencies. This information is widely trusted and distributed by various actors. It is not indisputable, however, as Stephen Haggard and Marcus Noland (2007; 2008) suggest. Both authors question the data circulated by the UN and claim that the FAO and the WFP particularly exaggerate the basic cereal needs of the North Korean population. They raise the critique that UN agencies overestimate the size of the population, "which would ex-

33 Beyond the academic realm, further information and data on North Korea are available on numerous websites, and blogs on the Internet. 
aggerate demand for grain" (Haggard/Noland/Weeks 2008a: 2). Further, they believe that the WFP and the FAO have overstated the role of grain in the North Korean diet. In a 2008 article for Newsweek magazine Haggard and Noland take issue with the WFP's estimation of North Korea's food shortage. They summarize the situation as follows:

Right now, the WFP says North Korea is short by about 1.67 million metric tons, which would mean famine conditions. Our estimate of the shortage $-100,000$ tons - means the real crisis is about to begin. The U.N. system's repeated invocations of a much larger gap have lulled people into a sense that North Korea is always short, and have obscured the actual conditions.

(“Asia's Other Crisis", Newsweek, 26 May 2008)

Hazel Smith (2008: 201), in turn, criticizes Haggard and Noland for their "dependence on contestable data, nonstandard conceptual interpretations (e.g., on the cereal balance), and contradictory chronological argumentation." She argues that scholarship needs more "than a methodology that relies on the allegedly baleful intent of the DPRK government as a deus ex machina to explain all outcomes" (ibid. 203, italics in original).

Another difficulty with the aid institutions' assessments of the food situation in North Korea concerns their neglect of the role and impact of private markets (jangmadang) and commercial activities (jangsa) on local food security (household level). As the WFP's handbook on food security assessments notes,

Markets move food to ensure that surpluses are transferred to areas where there is unmet demand [...] markets help to determine local food availability. The cost of trading (buying, storing, moving, selling) plus profit margins determines the price of food. Therefore markets have a strong impact on food access.

(WFP 2005: 49)

Since 2002, when small-scale economic market reforms were implemented in North Korea, jangmadang and jangsa activities have become popular throughout the country. Some studies have credited them with having a fundamental impact in meeting the people's basic food requirements and daily necessities (e.g., Smith 2009; Kim/Song 2008; Lee YH 2008 Kim/Song 2008, Lankov/Kim 2008; Reber 2008). ${ }^{34}$ Other estimations from external economists suggest that "at least half the calories consumed by the population" stem from food which is sold in markets (Harden 2009). A study by Kim Byung-yeon and Song Dong-ho (2008) reveals that so-called informal economic activities account for almost 80 percent of the total income of

34 Private business activities and local markets also played a significant role as an alternative mechanism to the governmental Public Distribution System prior to the 2002 trade liberalization. Some surveys (Lee YH 2008; Lankov/Kim 2008) point to the importance of jangmadang and jangsa activities at the end of the 1990s, when economic and humanitarian conditions reportedly deteriorated severely in North Korea. However, it can be said that the North Korean government's so-called "July 1 measures" of 2002 reinforced the importance of these activities. 
North Korean households. These informal activities include the consumption, trading, bartering, or sale of self-cultivated food and manufactured goods at markets. Other studies (e.g., Kim/Song 2008: 366-367) suggest that the share of informal earnings as a percentage of North Korean households' total income is as high as 90-98 percent. These findings point to the significance of local markets as the main source of food (and, partially, income), as opposed to the Public Distribution System (PDS), which is run by North Korean authorities and used by the WFP for the rationing of food..$^{35}$ The results imply that the importance of markets for North Korean people also has to be considered in assessments of the country's overall food situation.

In other words, if markets in North Korea are, according to UN agencies, "important sources of additional income" and food (EMOP 2008: paragraph 3,9) but cannot be considered in a "detailed analysis of market contribution to household food security" (CFSAM 2008: 25), pivotal mechanisms for the delivery and exchange of goods and services are being left out of the food security analysis. Questions regarding the completeness of such a study can thus be raised, as one of the central pillars of food security - food accessibility (WFP 2005: 31-32) - is not being (or cannot be) considered in evaluations of the food situation. ${ }^{36}$ Other scholars (e.g., Dalton et al. 2009; Lankov/Kim 2008) argue that gender aspects should also be considered in order to adequately evaluate food security and the economic situation in North Korea since women play a central role in securing, producing, and trading food for their families in the informal sector.

\section{Conclusion}

The main aim of the paper has been to highlight the role and importance of representational practices on the part of humanitarian actors in the constitution of North Korea's food reality. It has been argued that the generation of knowledge by aid organizations is related to with the formation of particular situations and social subjects. Consequently, the meaning of a phenomenon such as the food situation in North Korea (for instance "secure" or "insecure") is not naturally inscribed in the phenomenon itself, but is rather associated with a discourse of knowledge, practices, theories and representations.

The argument regarding the "discursiveness" of meaning and reality is not meant to suggest that aid workers deliberately fabricate famine, hunger, or starvation. The author's intention has not been to question humanitarian aid efforts in general or in particular. Rather, it has

35 Snyder (2003b: 119) explicitly criticizes the WFP for its reliance on the PDS, stating, "The amount of food distributed through the PDS is no longer an accurate indicator of imminent distress within the North Korean system, yet it has remained the WFP's primary indicator of distress and the primary vehicle through which the WFP distributes food inside the country."

36 It should be noted that information on markets and price levels in North Korea is said to be sensitive and therefore difficult to obtain. 
been to show how the discourse of food (in)security has become one of the main practices through which North Korea's reality is signified. It has become almost natural to privilege knowledge that takes for granted alarming reports about North Korea's food situation. The country appears to be in a constant state of humanitarian crisis; this leads to the prioritization of food shipments and UN assessments over development assistance and alternative projections.

Recalling briefly Foucault's (1977) examination of the prison system, according to which delinquents were produced through the emergence of the prison and its concomitants, such as criminology and law, we may similarly conclude that, like prisons - which do not prevent but rather produce crime-the practices of food aid do not avert food insecurity but rather bring it into being.

Some of the original insights and perspectives provided in this paper provoke questions concerning the general realm of international humanitarian affairs. From a broader perspective, food insecurity or hunger appears to be a problem limited exclusively to so-called underdeveloped and developing countries. For instance, the latest issue of the annual Global Hunger Index, published in October 2009 on the occasion of the World Hunger Day, maps hunger only for Central and South America, Africa, and most parts of Asia (IFPRI 2009). North America, Europe, Australia, South Korea and Japan are literally left blank, thereby raising questions about the reasons behind the omission of the measurement practices that are applied in poorer countries. When the same widespread indicators for measuring food (in)security are applied to the latter regions, it turns out that millions of people in these "developed" countries are similarly without "economic access to sufficient, safe and nutritious food to meet their dietary needs and food preferences for an active and healthy life" (WFS 1996). For instance, a report carried out under the auspices of the US Department of Agriculture using the same food security definition identified 36.23 million people or approximately 11 percent of households in the United States as food insecure (Nord et al. 2008). Over 12 million of these people were children (ibid. 7). If the "active and healthy" elements of the food security definition are also applied to the more wealthy countries, their food security can also be questioned-for instance, if one thinks of the trend of increasing child and adult obesity. That the issue of food insecurity in these regions is not problematized in terms of international food assistance, vulnerability, and the inability of governments to adequately feed their own people points to the political character of the issue and illuminates the power relations in play in global politics. 


\section{Bibliography}

Benthall, Jonathan (1993): Disaster, Relief and the Media. London: I.B. Tauris.

Bleiker, Roland (2001): The Aesthetic Turn in International Political Theory, in: Millennium: Journal of International Studies, 30 (3), pp. 509-533.

Bleiker, Roland (2006): Art After 9/11, in: Alternatives, 31, pp. 77-99.

Bleiker, Roland / Kay, Amy (2007): Representing HIV/AIDS in Africa: Pluralist Photography and Local Empowerment, in: International Studies Quarterly, 51 (1), pp. 139-163.

Butler, Judith (2009): Frames of War: When Is Life Grievable?. London: Verso.

Campbell, David (1998): Writing Security: United States Foreign Policy and the Politics of Identity. Revised edition. Minneapolis/ Manchester: University of Minnesota Press/ Manchester University Press.

Campbell, David (2003): Representing Contemporary War, in: Ethics \& International Affairs, 17 (2), pp. 99-108.

Campbell, David (2007): Poststructuralism, in: Dunne, T. / Kurki, M. / Smith, S. (eds.): International relations theories: discipline and diversity. Oxford: Oxford University Press, pp. 203-228.

CFSAM (2008): FAO/WFP Crop and Food Security Assessment Mission to the Democratic People's Republic of Korea. Rome: Food and Agriculture Organization of the United Nations, World Food Programme.

Chae, Suchan / Zang, Hyoungsoo (2002): Interim Development Assistance for North Korea A Multilateral Approach, in: International Journal of Korean Studies, 6 (1), pp. 137-149.

Choi, Choel Hee (2008): Balance of Principle and Flexibility Are Needed When Providing Food Assistance to North Korea, in: NK Daily, 16.06., http://www.dailynk.com/english/ read.php?cataId=nk00400\&num=3716 (13.05.2009).

Dalton, Bronwen / Jung, Kyungja / Lee, Mikyoung (2009): Capitalism with a female face? Women and economic change of North Korea. Paper prepared for the International Convention of Asia Scholars 6, Daejeon, Republic of Korea.

Doty, Roxanne Lynn (1996): Imperial Encounters: The Politics of Representation in NorthSouth Relations. Minneapolis, MN: University of Minnesota Press.

Eberstadt, Nicholas (1999): The end of North Korea. Washington, DC: American Enterprise Institute Press.

Eberstadt, Nicholas (2007): The North Korean economy: between crisis and catastrophe. New Brunswick, New Jersey: Transaction.

ECHO (2008): Evaluation of ECHO's Actions in the Democratic People's Republic of Korea (2004-2007). Brussels: European Commission's Directorate General for Humanitarian Aid. 
Edkins, Jenny (2000): Whose Hunger? Concepts of Famine, Practices of Aid. Minneapolis: University of Minnesota Press.

EMOP (2008): 10757.0- Emergency Assistance to Population Groups Affected by Floods and Rising Food and Fuel Prices. Rome: World Food Programme.

Epstein, Charlotte (2008): The Power of Words in International Relations Birth of an AntiWhaling Discourse. Cambridge: The MIT Press.

FAO (2006): Integrated Food Security and Humanitarian Phase Classification (IPC) Framework. Rome: Food and Agricultural Organization.

Feffer, John (2006): North Korea and the Politics of Famine. Silver City, NM and Washington, DC: Foreign Policy in Focus.

Flake, L. Gordon / Snyder, Scott (eds.) (2003): Paved with Good Intentions The NGO Experience in North Korea. Westport, Connecticut: Praeger.

Foucault, Michel (1970): The Order of Things: An Archaeology of the Human Sciences. London: Tavistock.

Foucault, Michel (1977): Discipline and Punish: The Birth of the Prison. London: Penguin Books.

Foucault, Michel (1980): Power/Knowledge Selected Interviews and Other Writings 1972-1977. New York: The Harvester Press Limited.

Foucault, Michel (1984): The Order of Discourse, in: Shapiro, M. J. (ed.): Language and Politics. Oxford: Basil Blackwell, pp. 108-138.

Foucault, Michel (1988): Madness and Civilization A History of Insanity in the Age of Reason. New York: Vintage.

Haggard, Stephan / Noland, Marcus (2007): Famine in North Korea Markets, Aid, and Reform. New York: Columbia University Press.

Haggard, Stephan / Noland, Marcus (2008): Famine in North Korea Redux?. Working Paper Series, edited by P. I. f. I. Economics. Washington D.C.: Peterson Institute for International Economics.

Haggard, Stephan / Noland, Marcus (2009): The North Korean Food Situation: Too Early to Break Out the Champagne, in: Asia Pacific Bulletin, (27), pp. 1-2.

Haggard, Stephan / Noland, Marcus / Weeks, Erik (2008a): North Korea on the Precipice on Famine. Policy Brief, edited by P. I. f. I. Economics. Washington D.C.: Peterson Institute for International Economics.

Haggard, Stephan / Noland, Marcus / Weeks, Erik (2008b): Markets and Famine in North Korea, in: Global Asia, 3 (2), pp. 32-38.

Hall, Stuart (1997): The Work of Representation, Hall, S. (ed.): Representation: Cultural representations and signifying practices. London: Sage, pp. 13-74. 
Halliday, Jon (1981): The North Korean Enigma, in: New Left Review I/127, (May-June), pp. $18-52$.

IFES (2008): DPRK Expecting Bumber Crop This Fall. NK Brief, edited by I. f. F. E. Studies. Seoul: Institute for Far Eastern Studies.

IFPRI (2009): 2009 Global Hunger Index. Bonn: International Food Policy Research Institute, Welthungerhilfe, Concern Worldwide.

Inayatullah, Naeem (2009): Why do some people think they know what is good for others?, in:

Edkins J. / Zehfuss, M. (eds.): Global Politics A New Introduction. London: Routledge, pp. 344-369.

Kim, Samuel (1997): North Korea and the United Nations, in: International Journal of Korean Studies, 1 (1), pp. 77-110.

Kim, Woon-keun / Lee, Hyun-ok / Sumner, Daniel (1998): Assessing the Food Situation in North Korea, in: Economic Development and Cultural Change, 46 (3), pp. 519-535.

Krishnan, R.R. (1981): North Korea and the Non-Aligned Movement, in: International Studies, 20, pp. 299-313.

Kwon, Tae-jin (2009): An Evaluation of the Food Situation facing North Korea and Prospects, in: Vantage Point, 32 (8), pp. 46-57.

Laclau, Ernesto (1993): Power and Representation, in: Poster, M. (ed.): Politics, Theory and Contemporary Culture. New York: Columbia University Press, pp. 277-296.

Laclau, Ernesto (1996): Emancipation(s). London: Verso.

Laclau, Ernesto (2000): Identity and Hegemony: The Role of Universality in the Constitution of Political Logics , in: Butler, J. / Laclau E. / Žižek, S. (eds.): Contingency, Hegemony, Universality: Contemporary Dialogues on the Left. London \& New York: Verso, pp. 44-89.

Laclau, Ernesto (2005): On Populist Reason. London \& New York: Verso.

Laclau, Ernesto / Mouffe, Chantal (2001): Hegemony and Socialist Strategy: Towards a Radical Democratic Politics. 2nd ed. London \& New York: Verso.

Lankov, Andrew (2008): N. Korea Faces Unprecedented Food Crisis Since 1990s, in: The Korea Times, 18 June.

Lankov, Andrew / Kim, Seok-hyang (2008): North Korean Market Vendors: The Rise of Grassroots Capitalists in a Post-Stalinist Society, in: Pacific Affairs, 81 (1), pp. 53-72.

Lautze, Sue (1996): North Korea Food Aid Assessment (May-June 1996). U.S. Agency for International Development.

Lee, Shin-wha (2003): International Engagement in North Korea's Humanitarian Crisis: The Role of State and Non-State Actors, in: East Asia, Summer, 20 (2), pp. 74-93.

Lee, Young-Hoon (2008): Changes in the North Korean Economy Reported by North Korean Refugees, in: North Korean Review, Fall, 4 (2), pp. 49-57. 
Lisle, Debbie (2009): How do we find out what's going on in the world?, in: Edkins, J. / Zehfuss, M. (eds.): Global Politics A New Introduction. London: Routledge, pp. 147-169.

Moeller, Susan D. (1999): Compassion Fatigue: How the Media Sell Disease, Famine, War and Death. New York: Routledge.

Morton, David (2007): Steep learning curves in the DPRK, in: Minear, L. / Smith, H. (eds.): Humanitarian diplomacy: Pracitioners and their craft. Tokyo: United Nations University Press, pp. 194-214.

Nathanail, Lola (1996): Small Fish in a Deep Dark Sea: NGO's Response in North Korea, in: Relief and Rehabilitation Network Newsletter, November, (6), pp. 6-8.

Natsios, Andrew S. (2001): The Great North Korean Famine. Washington D.C.: United States Institute of Peace Press.

Noland, Marcus (1997): Why North Korea Will Muddle Through, in: Foreign Affairs, 76 (4), pp. 105-118.

Noland, Marcus (2008): Obama, world should focus on N.K. famine, in: The Korea Herald, 27.11.08.

Nord, Mark / Andrews, Margaret / Carlson, Steven (2008): Household Food Security in the United States, 2007. Edited by United States Department of Agriculture.

Pinkston, Daniel A. / Saunders, Phillip C. (2003): Seeing North Korea Clearly, in: Survival, 45 (3), pp. 79-102.

Postman, Neil (1987): Amusing Ourselves to Death: Public Discourse in the Age of Show Business. London: Methuen.

Pusca, Anca (2009): Walter Benjamin, a Methodological Contribution, in: International Political Sociology, 3 (2), pp. 238-254.

Reber, Dirk (2008): Die Arbeit der Welthungerhilfe in Nordkorea, in: Koreaforum (1+2), pp. 84-86.

Reed, Edward P. (2005): The Role of International Aid Organizations in the Development of North Korea: Experience and Prospects, in: Asian Perspective, 29 (3), pp. 51-72.

Reed, Edward P. (2008): Famine's Aftermath: Retrenchment or Reform?, in: Asia Policy, 5, pp. 186-189.

RFSA (2008): Rapid Food Security Assessment: Executive Summary: Food and Agriculture Organization of the United Nations, World Food Programme.

RRN, Relief and Rehabilitation Network (1997): Democratic People's Republic of Korea, in: RRN Newsletter, November, pp. 29-31.

Said, Edward W. (1978): Orientalism. Harmondsworth: Penguin.

Scalapino, Robert (1997): Introduction, in: Suh, D.-S. / Lee, C.-J. (eds.): North Korea After Kim Il Sung. London: Lynne Rienner Publishers, pp. 1-12. 
Schloms, Michael (2003): The European NGO Experience in North Korea, in: Flake, L. G. / Snyder, S. (eds.): Paved with Good Intentions. The NGO Experience in North Korea. Westport, Connecticut: Praeger, pp. 47-80.

Schloms, Michael (2004): North Korea and the Timeless Dilemma of Aid. A Study of Humanitarian Action in Famines. Münster: Lit Verlag.

Schwekendiek, Daniel (2008): The North Korean standard of living during the famine, in: Social Science \& Medicine, 66, pp. 596-608.

Schwekendiek, Daniel (2009): Statistical Explorations in Terra Incognita: How Reliable are North Korean Survey Data?, in: Frank, R. / Hoare, J. E. / Köllner, P. / Pares, Susan (eds.): Korea Yearbook 2009. Politics, Economy and Society. Leiden: Brill Academic Publishers, pp. 277-300.

Shapiro, Michael J. (1988): The politics of representation: Writing practices in biography, photography, and policy analysis. Madison: University of Wisconsin Press.

Smith, Hazel (1999): 'Opening up' by default: North Korea, the humanitarian community and the crisis, in: The Pacific Review, 12 (3), pp. 453-478.

Smith, Hazel (2000): Bad, mad, sad or rational actor? Why the 'securitization' paradigm makes for poor policy analysis of North Korea, in: International Affairs, 76 (3), pp. 593-617.

Smith, Hazel (2005): Hungry for Peace International Security, Humanitarian Assistance, and Social Change in North Korea. Washington D.C.: United States Institute of Peace Press.

Smith, Hazel (2007): Food security: The case for multisectoral and multilateral cooperation, in: Smith, H. (ed.): Reconstituting Korean Security. A Policy Primer. Tokyo: United Nations University Press, pp. 82-102.

Smith, Hazel (2008): North Korea as the Wicked Witch of the East: Social Science as Fairy Tale, in: Asia Policy, January, (5), pp. 197-203.

Smith, Hazel (2009): North Korea: Market opportunity, poverty and the provinces, in: New Political Economy, 14 (2), pp. 231-256.

Snyder, Scott (2003a): The NGO Experience in North Korea, in: Flake, L. G. / Snyder, S. (eds.): Paved with Good Intentions. The NGO Experience in North Korea. Westport, Connecticut: Praeger, pp. 1-14.

Snyder, Scott (2003b): Lessons of the NGO Experience in North Korea, in: Flake, L. G. / Snyder, S. (eds.): Paved with Good Intentions. The NGO Experience in North Korea. Westport, Connecticut: Praeger, pp. 111-122.

UN (1999): Mid-Term Review of the 2001 United Nations Consolidated Inter-Agency Appeal for the Democratic People's Republic of Korea January to June 1999. New York: United Nations Office for the Coordination of Humanitarian Affairs. 
UN (2000): Consolidated Inter-Agency Appeal for the Democratic People's Republic of Korea January to June 2000. New York: United Nations Office for the Coordination of Humanitarian Affairs.

UN (2001): Mid-Term Review of the 2001 United Nations Consolidated Inter-Agency Appeal for the Democratic People's Republic of Korea. New York: United Nations Office for the Coordination of Humanitarian Affairs.

Van Houtryve, Tomas (2009): The Land of No Smiles, in: Foreign Policy, May/June, http://www.foreignpolicy.com/story/cms.php?story_id=4878 (24.08.2009).

Vaughan-Williams, Nick (2005): International Relations and the 'Problem of History', in: Millennium: Journal of International Studies, 34 (1), pp. 115-136.

WFP (2005): Emergency Food Security Assessment Handbook. Rome: World Food Programme. 


\section{G

\section{Recent Issues}

No 121 Daniel Flemes and Thorsten Wojczewski: Contested Leadership in International Relations: Power Politics in South America, South Asia and Sub-Saharan Africa; February 2010

No 120 Annegret Mähler: Nigeria: A Prime Example of the Resource Curse? Revisiting the OilViolence Link in the Niger Delta; January 2010

No 119 Nicole Hirt: “Dreams Don't Come True in Eritrea": Anomie and Family Disintegration due to the Structural Militarization of Society; January 2010

No 118 Miriam Shabafrouz: Oil and the Eruption of the Algerian Civil War: A Context-sensitive Analysis of the Ambivalent Impact of Resource Abundance; January 2010

No 117 Daniel Flemes and Michael Radseck: Creating Multilevel Security Governance in South America; December 2009

No 116 Andreas Mehler: Reshaping Political Space? The Impact of the Armed Insurgency in the Central African Republic on Political Parties and Representation; December 2009

No 115 Malte Gephart: Contextualizing Conceptions of Corruption: Challenges for the International Anti-corruption Campaign; December 2009

No 114 Andreas Mehler: The Production of Insecurity by African Security Forces: Insights from Liberia and the Central African Republic; November 2009

No 113 Miriam Shabafrouz: Iran's Oil Wealth: Treasure and Trouble for the Shah's Regime. A Context-sensitive Analysis of the Ambivalent Impact of Resource Abundance; November 2009

No 112 Annegret Mähler: Oil in Venezuela: Triggering Violence or Ensuring Stability? A Contextsensitive Analysis of the Ambivalent Impact of Resource Abundance; October 2009

No 111 Martin Beck: Oil-rent Boom in Iran?; October 2009

No 110 Juliane Brach and Robert Kappel: Global Value Chains, Technology Transfer and Local Firm Upgrading in Non-OECD Countries; October 2009

No 109 Heinz Jockers, Dirk Kohnert and Paul Nugent: The Successful Ghana Election of 2008 - a Convenient Myth? Ethnicity in Ghana's Elections Revisited; September 2009

No 108 Sebastian Huhn: The Culture of Fear and Control in Costa Rica (II): The Talk of Crime and Social Changes; September 2009

All GIGA Working Papers are available free of charge at www.giga-hamburg.de/workingpapers. For any requests please contact: workingpapers@giga-hamburg.de.

Editor of the Working Paper Series: Juliane Brach 